\title{
The Benefits of Accounting Information On The Intention of Stocks Selections In Indonesia Stock Exchange (IDX)
}

\author{
MF. ARROZI ADHIKARA* \\ Universitas Esa Unggu \\ MASLICHAH \\ NUR DIANA \\ Universitas Islam Malang
}

\begin{abstract}
This research objective is to both examine and provide empirical evidence concerning analysts' decision-making intentions in choosing stocks at the Indonesian stock exchange by using accounting information. This research uses a causalexplanatory approach in examining the analysts' intentions on selecting stocks. This research uses primary data with questionnaire-surveys and adopts single study. In explaining the analysts' intentions, this research uses a causal-explanatory approach. This research shows that the benefits of accounting information (1) positively affect beliefs revisions; (2) positively affect unsystematic risk perceptions; (3) positively affects the intention of stock selections; (4) positively affect the intention of stock selections; (5) positively affect the intention of stock selections; (6) negatively affects the intention of stock selections; and (7) positively affect the intention of stock selections. Further, this research also finds that securities analysts behaved sophistically in analyzing accounting information for decision-making purposes. Accounting information has characteristics (i.e., relevant, reliable, and fair) that in alignment with the interests of its users. The intention for stock selection is driven by the knowledge and experiences of both the respondents as well as other people. This condition shows that there is a halo effect surrounding the intention for stock selections that come from people that other than respondents (e.g., respondents' colleagues). Therefore, securities analysts tend to act prudence, sophisticated, volitional, and risk neutral.
\end{abstract}

Keywords: Beliefs Revision, Subjective Norm, Risk Perception, Intention Stock Selection

Intisari: Tujuan penelitian ini adalah untuk menguji dan memberikan bukti empiris tentang niat pengambilan keputusan analis dalam memilih saham di bursa efek Indonesia dengan menggunakan informasi akuntansi. Penelitian ini menggunakan pendekatan kausal-explanatory dalam menguji niat analis untuk memilih saham. Penelitian ini menggunakan data primer dengan survei kuesioner dan mengadopsi studi tunggal. Dalam menjelaskan niat analis, penelitian ini menggunakan pendekatan penjelasan kausal. Penelitian ini menunjukkan bahwa manfaat informasi akuntansi (1) secara positif mempengaruhi revisi keyakinan; (2) secara positif mempengaruhi persepsi risiko yang tidak sistematik; (3) secara positif mempengaruhi niat pemilihan

*Corresponding author: maslichah62@yahoo.co.id 
saham; (4) secara positif mempengaruhi niat pemilihan saham; (5) secara positif mempengaruhi niat pemilihan saham; (6) secara negatif mempengaruhi niat pemilihan saham; dan (7) secara positif mempengaruhi niat pemilihan saham. Selanjutnya, penelitian ini juga menemukan bahwa analis sekuritas berperilaku secara canggih dalam menganalisis informasi akuntansi untuk tujuan pengambilan keputusan. Informasi akuntansi memiliki karakteristik (yaitu, relevan, andal, dan adil) yang selaras dengan kepentingan penggunanya. Niat untuk pemilihan saham didorong oleh pengetahuan dan pengalaman baik dari responden maupun orang lain. Kondisi ini menunjukkan bahwa ada efek halo yang mengelilingi niat untuk pemilihan saham yang berasal dari orang-orang yang selain responden (misalnya, rekan responden). Oleh karena itu, analis sekuritas cenderung bertindak bijak, canggih, kehendak, dan risiko netral.

Kata Kunci: Revisi Keyakinan, Norma Subyektif, Persepsi Risiko, Intention Stock Selection

\section{Introduction}

Indonesian capital market belongs to an emerging market (Prabowo, 2000). This market has several characteristics. First, the investors respond information naively and unsophisticatedly. They have limited skills to analyze and interpret information coming. Second, they do not use the role of financial report as the support of decision taken investment optimally yet which it is relatively small in the Indonesian capital market. Third, the investors receive the misdistribution information with a small capability to analyze financial report. Thus, investors tend to find the fundamental aspect of an issuer by their own ways.

Based on the above case, assessing stocks needs the role of an effective analysis to give recommendation and advisory to the investors in the best stock finding through purchase and sale. It aims to know and predict the price of capital share reasonably and precisely on the specific time and has a role as the essential reference for investors in an investment of capital share (Agung et al., 2007). The effect analysis recommendation influences the price of a capital share and market share. Securities analyst recommendations are divided into two categories, namely: recommendations based on fundamental and technical (Cash OnLine, December 14, 2008). Fundamental recommendations use the company's performance in the past and the prospect's 
performance for the future. Thus, it is good to use uncomplicated model, easy to understand, and self-based on accounting information (Investor 2007; Suad, 2006). It demands quality and transparency of information, especially accounting information as a shaper of market efficiency. This information is laden with issues, substances, and the knowledge to use securities analysts and other users in the decision predicting stock prices (Hartono, 2008; SFAC 1, 1978). Meanwhile, technical recommendations depend on an assessment of an analysis of the changes in short-term investments stock prices.

The main issue of this research was to question the intentions of securities analysts in the stock selection of candidates. Intention analysts effects are reflected in stock returns as a result of the information. The intention becomes a concern for foster information cultivate the intention to conduct which become normative when the user has only limited direct experience and time (Hartwick and Barki, 1994). Ajzen and Fishbein (1980) assume humans behave consciously because of information consideration and behavior dneid. The changes in stock prices is a reflection of all information when the information is used, to increase knowledge, change beliefs, decisions, and actions of the analyst with the revision of the stock. Intention stock selection is formed of factors which indicate how much planned effort and depend on the individual characteristics, social pressure, and environment. This factor changes according to time so that the motivation changes as an indication to influence intentions (Ajzen, 1988).

The first motivation in this study is the small issues empirically in this study in the capital market. IDX is an emerging market with a speculative decision making, influenced by opinion and mass psychology. Decision-making in the fields of accounting and finance focus on the use and evaluation of accounting information through fundamental analysis. Secondly, the opportunities develop the Theory of Reasoned Action Model for behavior will not refuse when it is affected by other variables of outside attitudes, subjective norms, and an intention to act, such as demographics, personality characteristics, the object trust, the attitude toward the object, the task characteristics, and the situational variables. Third, the inconsistency 
results in a simultaneous relationship among the accounting information benefits, risk perception, belief revision, and intentions in the act.

The research objective is to assess and obtain empirical evidence of the effects analysts behavior in the decision making of candidate stock selection at the Indonesian Stock Exchange by using information usefulness. This research has three contributions. The first is for behavioral accounting knowledge by using a decisionmaking perspective of stock selection. Second, it contributes to issuers and management accountants in improving the disclosure of financial statements either mandatory or voluntary. Third, this study is useful for the next accounting behavioral researchers with their upcoming research as the study of the decision-making process in the financial sector.

\section{Theoretical Framework and Hypothesis Development}

\subsection{Theory of Reasoned Action}

Theory of Reasoned Action developed by Fishbein and Ajzen (1975) stated that behavior is done because people have the intention to do so and relate to the activities carried out on their own volitional behavior. Antecedents causing volitional behavior is based on assumptions: first, people sensibly do things. Second, humans consider all of the information. Third, they count the implications of their action.

The outline of the reasonable action concept is divided into three relationships. First is the relationship between the attitude and the confidence. The belief caused by behavior is the component containing knowledge. Knowledge has a positive or negative result due to take part in the action. Beliefs affect attitudes for positive or negative influence knowledge which means attitudes toward action is formed of knowledge. The implication, attitudes can be positive or negative depending on the knowledge components which form a faith. Second, the relationship between the normative beliefs and subjective norms. Normative beliefs of the behavior is a component of knowledge and views of others which affect a person's life. It is compulsory or not if someone will participate in an action. The subjective norm towards action is a person's decision after considering the others' views in action. A 
person can be affected or not depending on the personal strength in the face of others' intention. The third is the relationship between attitude and subjective norms with the intention to behave. An intention to act depends on the intention to commit an act, and the intention is formed of attitudes towards action and subjective norms towards an action. This theory reveals that someone would commit an act when he looked at the act positively and believe that other people want him to do it.

\subsection{Information Usefulness}

The useful accounting information should have relevant and reliable information quality (Scott, 2011) and value in increasing knowledge. Also, it should add confidence regarding the probability of the expectations realization in uncertainty conditions and modify the decision or the behavior of users (Suwarjono, 2008). Financial Accounting Standards Board / FASB (1980) successfully arranged a report standard qualitative through Standard Financial Accounting Concepts (SFAC) No. 2 which shows the "Qualitative Characteristics of Accounting Information" which is a requirement that must be met for information purposes following SFAC No. 1 to be able to achieve. The quality characteristics of accounting information shows the financial report which should have values as follows:

a. Primary quality. SFAC No. 2 stated that qualities which distinguish useful information from unuseful information are relevant and reliable. Two primary qualities that make the useful accounting information for decision making are: first, relevance. The relevance of accounting information should be able to make a difference in a decision. Accounting information should have a predictive value, a feedback value, and punctuality so that it would be relevant. Second, reliable is information that can be relied on if it is free of errors, irregularities, and an honest presentation. Accounting information has identifiable characteristics, honesty, and neutral presentation

b. Secondary Quality. The information would be more useful if you have a secondary quality characteristic which is comparable and consistent. 
c. Limitations of Financial Statements. Accounting information is helpful if it reaches a minimum level of relevance and reliability. This represents a limitation for the useful information. The characteristics limitations are cost and benefit as well as materiality.

\subsection{Revision of our faith/belief's revision}

Fishbein and Ajzen (1975) gives a view of beliefs as a component containing knowledge about $\mathrm{X}$. This component is either positively or negatively occurs because of participation in an $\mathrm{X}$. X knowledge, in this case, is the opinion about something that may not necessarily correspond to reality. In the context of accounting, belief is a critical component in the decision-making process. It determines the behavior of decision-making (Beaver, 1989). The role of information is to change the belief so that decision-making behavior would change when new information arrives. Investor beliefs are invisible. The stock price may be regarded as the appearance of an equilibrium process of investors' confidence.

Confidence revision shows investor to conduct beliefs revision about stock prices when receiving information in the form of dividends and earnings surprises (Hogarth and Einhorn's, 1992). The assumption is that people change beliefs through a sequence of anchoring and adjustment process. Current belief is useful as an initial belief that would be adjusted to new beliefs continuously in sequence. This theory also considers the strength of the initial belief (anchor) and predicts that a large anchor will be reduced by negative information than a small anchor, and vice versa. It is called the anchoring effect. Scott (2011) gives a prediction of investor behavior in response to the financial statements' information, namely:

a. Investors have a belief about expected return and risk issuer shares. This belief is based on available information in the market, including the market price up before the publishing of the company's net profit. However, those beliefs are not the same because it's different inputting information and interpretation capabilities.

b. After the issuance of the current year's net profit, investors will become more informed by analyzing profit figures. For example, if the net profit is higher than 
the expected one, then it becomes good news. Some investors will revise his beliefs regarding the earnings power and returns in the future. Other investors who have high expectations about how much net profit should interpret the same net income as bad news. Investors who have revised their beliefs regarding a higher future profitability returns incline to purchase company stock at the current market price.

\subsection{Risk perception}

Perception is an individual view in understanding the object or event by faculty. This view is gained from experience about the object by concluding information and interpreting the message. Perceptions are subjective and situational because the object depends on the framework of space and time so that the individual's perception of an object possibly has differences with the other individual's perception of the same object (Dictionary of Indonesian, 1995; Matlin, 1998; Robbins, 1996).

Investment risk is a deviation from the expected profit (Jones, 2006). Risks are often associated with deviations from the accepted outcome to the expected one. The uncertainty means investors will receive an unvalued return in the future (Hartono, 2008). Market participants should be familiar with the type of risks divided into two major groups to reduce investment risk, i.e. systematic risk and unsystematic risk (Jones, 2006). First is the systematic risk. It is a market risk that can not be eliminated through diversification of the portfolio. The value of a well-diversified portfolio will fluctuate to changes in market returns results. For example, a sharp rise in inflation, recession, interest rate hikes, and the economic cycle. Market players conduct a protected value in the futures market or options market.

Second is an unsystematic risk. It is the specific risks for each company including the policies and the strategic decisions, the operations, and the corporate finance. This risk differs among the various companies that focus on a specific impact on the stock or sector. For example, government regulations prohibit export or import cement which affects the issuer's stock price which produces cement, property, or other products made from cement materials. To reduce losses, market players invest in 
various types of stocks from different sectors. If one type of stock loses out, there are still other profit stocks.

According to analysts, a risk of base stocks is the risk of stocks selection including stocks taking that has lower adverse selection return from the average return of the company size or in the same industry/the sector (Selva, 1995; Ricciardi, 2004). Analysts minimize the risk through comparisons of the company's prospects in the same industry and pick stocks which the increase of potential price exceeds the rise in stock indexes. Analysts examine the company size, capital structure, and geographical segments to see the level of industrial risks. Hopefully, the risk level relates to the future earnings and equalize rising stock prices with earnings.

Risk perception has subjective components including beliefs, attitudes, and feelings towards risk for specific situations, as well as the hazard. Thus, the risk perception is shown from others' perception about the possibility of getting potential exposure to loss, harm, or crimes related to specific activities (Ricciardi, 2004). The risk perception is an individual view based on how intense he experiences financial risks exposure for the use of financial statements (Koonce, 2004). The risk perception is an integrated model that combines behavioral risk characteristics with the risk in the standard deviation theory (probability and expected value) related to losses and gains. The study of the premise is the perception of financial report users which is better understood and explained by incorporating behavioral risk characteristics. These merging models gains empirical support.

\subsection{Empirical Study}

\subsubsection{The Relation of Accounting Information Benefits towards Beliefs Revision}

Scott (2011) and Beaver (1989) states that accounting information content information if it helps investors to revise beliefs in the decision-making process of selling and purchasing stocks so that it helps the beliefs revision of earnings expectations and expected proxy on changes in prices and trading volumes. The study results of Easton and Zmijewski (1989) shows for every $\$ 1$ good news or bad news in the earnings report, analysts increase or decrease the next quarter earnings forecast by 
34 cents above the average and state indirectly that the company's financial statements are informative. Stuerke (2005) showed a positive relationship between the analysts' forecast revision after the earnings announcement interim with ERC, the strength of earnings surprises, and earnings-returns. The results of the study are the benefits of earnings announcements related to new information, the innovation ERC, and the earnings uncertainty. Barberis and Thaler (2003) stated in the rational expectation equilibrium that investors are rational and consistent beliefs. It means when the investors receive new information, they change beliefs correctly and make a choice normatively acceptable. This shows that investors are not only processing information correctly, but also competently.

The role of financial statements in economic decisions contributed to the contrary. Epstein study (1975) showed that $45.2 \%$ of shareholders were not based on the financial statements. They concluded that the annual financial statements do not provide information for the benefit of shareholders in decision-making. Studies Chen and Hsu (2005) shows the contradictory findings that the information company news and advice contributed higher than the presented financial statements to change the investors' beliefs and actions. Perception of Hong Kong investor stated that the relevant quality is more important than the reliable quality.

\subsubsection{Relations of Accounting Information Benefits towards Unsystematic Risk} Perception

Research shows that the benefits of accounting information influence the unsystematic risk perception by the study results of Beaver et al. (1970), Lee (1999), Koonce et al. (2004), as well as Capstaff (1992). Users have beliefs to the company that experiences financial difficulties, illiquid, worrying financial situation, or the stock possibility is called risky instruments. That is why it has risk perception. Users control the unsystematic risk by diversification of variations in the type of companies, industries, and composition. Thus, users take the attitude towards risk based on risk preferences including risk averter, risk seekers, or risk neutral. The benefits of accounting information do not affect the unsystematic risk perception by Lambert and Verrechia study (2005) and Ferris et al. (1990). Accounting information indicates the 
performance, prospects, and the company value. Information is responded positively by users because the company does not experience financial difficulties and liquidity. Perception users showed the company's shares that are not at risk and have neutral risk preferences.

\subsubsection{The Relationship of Beliefs Revision towards Stocks Election Intention}

Bruns (1968) proved that beliefs determine decision-making behavior in taking action because of the interpretation from the information. Through the understanding information process center of cognitive such as memory, attention, perception, thinking, knowledge and judgment occurs on intentions process to estimate the return on stocks of interest. Investors give different results because of differences in knowledge and beliefs. Wahlund and Gunnarsson (1996) show the intentions are influenced by differences in cognitive capacity and the type of investment decision. Differences in cognitive capacity indicate to limitations of capacity memory in performing information processing sequentially. This shows that an individual understands how to conceptualize and interpret events to provide information. Because of the cognitive limitations, the individual will be different in making a judgment. The results of different studies is a negative relationship by adding an ethical belief variable to explain individual behavior in taking a decision (Blanthorne, 2000). The study shows that the ethical beliefs have the negative impact and the most significant influence on the intention to behave disobediently.

\subsubsection{The Relationship of Unsystematic Risk Perception towards Election Stocks Intention}

The unsystematic risk perception reflects the views of users about the potential loss on those financial statements items so that the company shares are at risk (Koonce et al., 2004). Perception of risk stocks showed an alarm condition of the poor company performance and prospects. Because the stock has not prospected, the user will evaluate individual stocks performance in the portfolio. The poor individual stocks performance will be removed and converted with the good share in performance and prospects. Thus, the intention of the decision-making in the stocks 
selection becomes high. This prediction is supported by the results study of Chen and Steiner (1990), and Gibson et al. (1997).

\subsubsection{The Relation of Subjective Norm toward Stocks Election Intention}

Subjective norms reflect the individual views toward the others' beliefs that will affect the intention of doing or not doing the behavior. The users get encouragement and motivation in the decision making of stocks selected from the experts to act like what they do. The high motivation is because of the high social pressure of experts taking action and getting an approval view for those actions (Bhattacherjee, 2000; Hailu et al., 2005; Hite, 1988; Shin et al., 1995; and the JSE Team, 1997).

\subsubsection{The Relations of Systematic Risk Perception towards the Stock Election Intention}

The Systematic risk derived from the external environment, such as the economic turbulence, the country's political conditions, changes and developments in information technology, public policy, financial market conditions, and changes in interest rates which is responded by the user. Thus, the user perceives the external environment cannot be predicted because of the out of control of the external aspects that will affect the entire trading mechanism in the form of stock price volatility at the Stock Exchange. The environment becomes uncertain capital markets, and securities prices become volatile and difficult to expect to anticipate volatility market. That conditions give a diverse expectation view of them so that they decide to hold than sell or purchase stock. This is based on the primary purpose to earn income within the time horizon of the increasing achievement in capital investment. The JSE study team demonstrates the study results (1997), Luo (1999), Kim and Lim (1988), as well as Goldberg and Von Nitzsch (2001).

\subsubsection{The Relations of Accounting Information Benefits toward Electoral intention} of Shares

The beliefs about selected stock candidates are based on the information of the financial statements issuer publication. Although stock analysts base on their beliefs in financial statement information, their beliefs are not the same as the difference in 
getting the information and having the ability to interpret the financial statements. Performers have the beliefs regarding the selected stocks candidates according to the financial performance of each stock. After the financial statements publication work, users read, analyze, and interpret financial statements. Thus, users become more informed from the accounting numbers analysis results in the financial statements. As a result, a user selects the stocks which gave belief in the stock performance and prospect because they provide information as good news, and do not choose stock because of the bad news. Users inclined to take a shares election through the share purchase of the company's current price (good news) and sell or retain the shares in its portfolio (bad news). This is related to Hogarth and Einhorn's study (1992), Beaver (1989), Barberis and Thaler (2003), Eipstein (1975), Easton and Zmijewski (1989), as well as Stuerke (2005).

Based on the study of the theoretical and empirical results, these are the following hypotheses:

H1. Benefits of accounting information influence the revision beliefs.

H2. The benefits of accounting information influence the unsystematic risk perception

H3. Beliefs revision affects the intention of stock selection.

H4. Unsystematic risk perceptions affect the intentions of stock selection.

H5. Subjective Norms effect to the intention of stock selection.

H6. Systematic risk perceptions affect the intentions of stock selection.

H7. The benefits of accounting information influence the intention of electoral stocks.

\section{Research Methods}

\subsection{Type and Design Research}

This research conducts an explanatory-causal approach to explain intentions phenomena in a stock election. The data source is primary. The time dimension is one shot study. The method of data collection conducted in a survey. The research data is in a subject data of securities analysts who express an opinion, attitude, justification, 
experience, or the subject characteristics in the decision making a stock selection. Respondents are securities analysts. The unit of analysis is the individual.

\subsection{Population Sample, and Sampling Techniques}

The study population is the securities analysts at the research and development of Security Company and incorporated in the Securities Analysts Association of Indonesia (AAEI). The large sample size according to Hair et al. (2007) is 5-10 x number of variables or the estimated maximum likelihood estimation (MLE) between 100- 200. The determined sample size from the MLE is 178 . The sampling technique uses simple random sampling which means that any securities analysts have equal opportunity to be selected as a sample.

\subsection{Mechanical Analysis}

Data analysis uses Structural Equation Model (SEM) with AMOS 4.01 program for the hypothesis test from 1 through 7 . This technique is appropriately used for relationship analysis to describe a stages series through path analysis.

\subsection{The Definition of Operational and Variables Measurement}

\subsubsection{The Benefits of Accounting Information}

The benefits of accounting information are the degree of positive or negative affect determined directly by the beliefs of the effect's analyst on the useful information quality in decision making. Instruments to measure the benefits of accounting information are developed by researchers from SAK (IAI, 2012), Ho and Wong (2005), and (Arrozi et al., 2013). The benefits of the accounting information identified into five latent variables and 15 measurable variables:

a. Relevance (IA1) consists of three indicators; such as prediction, feedback, and punctuality.

b. Reliability (IA2) consists of three indicators; such as accountable, symbolization accuracy, and neutral. 
c. Quality Secondary (IA3) consists of three indicators; such as comparative, consistency, and understandable.

d. Limitations (IA4) consists of two indicators; such as the costs and benefits; and Materiality.

e. Performance (IA5) is composed of two indicators; such as short-term performance, and prospects.

Instruments of accounting information benefit are developed by Likert scale. This scale measures the usefulness information with the figure 1 which shows the unuseful accounting information, as well as figure 5 which shows the helpful accounting information.

\subsubsection{Unsystematic Risk perception}

Unsystematic risk perception is a belief of securities analysts regarding the financial statement items considered to a potential loss of yield. Unsystematic risk perception instrument consists of 7 indicators developed by Koonce et al. (2004), namely:

a. The financial statements show the financial difficulties (RU1).

b. Fears of company financial condition (RU2).

c. Uncontrolled Financial condition (RU3).

d. Relations of financial risk with the time occurrence (RU4).

e. Economic losses probability of financial statements (RU5).

f. Loss prediction happened to the company (RU6).

g. Financial risk occurrence in the company (RU7).

Unsystematic risk instruments use a Likert scale that measures the unsystematic risk by the numeral 1 with not risky indication and very risky on figure 5 .

\subsubsection{Beliefs revision}

Beliefs revision is a change of primary beliefs (anchor) into a new belief (adjustment) for securities analysts to acquire the information as the good news or the bad news. The instrument of beliefs revision counter is developed from Hogarth and Einhorn's (1992) and Scott (2011), which consists of six indicators, namely: 

a. Earnings brought the news (RK1)
b. Return carry information content (RK2)
c. Dividend brought the news (RK3)
d. Dividends carry information content (RK4)
e. Price Earning Ratio Performance contains positive information (RK5)
f. Performance encourage candidate change (RK6)

The instruments of belief revision counter use a Likert scale. This scale shows very unsure in figure 1 and very confident in figure 5.

\subsubsection{Subjective norms}

Subjective norm is the perception of securities analysts about the influence strength of people's views who are experts in the field of financial investment that motivates them to conduct the stock selection. The variable of subjective norms are developed from Chow and Chan (2008) and East R. (1993) with four indicators, such as Observer Influence (NS1), Friends Influence (NS2), Mass Media Influence (NS3), and Regulator Influence (NS4)

Subjective norm instrument is made by a Likert scale measuring the strength of normative beliefs to obey the investment decision taken. Provided answers are started from very discouraging (1) to strongly encouraging (5).

\subsubsection{Systematic Risk Perception}

Systematic risk perception is not predicted by various aspects of their external environment accurately. The instrument counter of systematic risk consists of 5 questions obtained by modifying the instrument created by Gordon and Narayanan (1984), as well as Farid and Siswanto (1998). Systematic risks are identified through

five indicators, namely: Economic (RS1), the Government (RS2), Politics (RS3), Financial Markets (RS4) and interest rate (RS5).

\subsubsection{Intention in Stock Selection}

Stocks Selection intention is the intention of selecting stocks candidate determined directly from the belief of securities analysts to the estimation on stock returns. Instruments are developed by the researchers from Wahlund and Gunnarsson (1996) and Arrozi (2012) with seven measured variables (indicators). They are 
namely: the desire to have stocks with high returns and the blue chips, the willingness for stocks information, the desire to revise the stock performance, the desire how to know the new investment, the desire to be responsive about the changes of stock prices and market interest rates.

Instruments intention in stock selections is developed using a Likert scale. Respondents are asked to respond with alternative answers provided ranging from very unintentional (1) to the very intentional (5).

\section{Research Model}

The research model is drawn in SEM on picture 1.

Figure 1

Model and Tracks Development

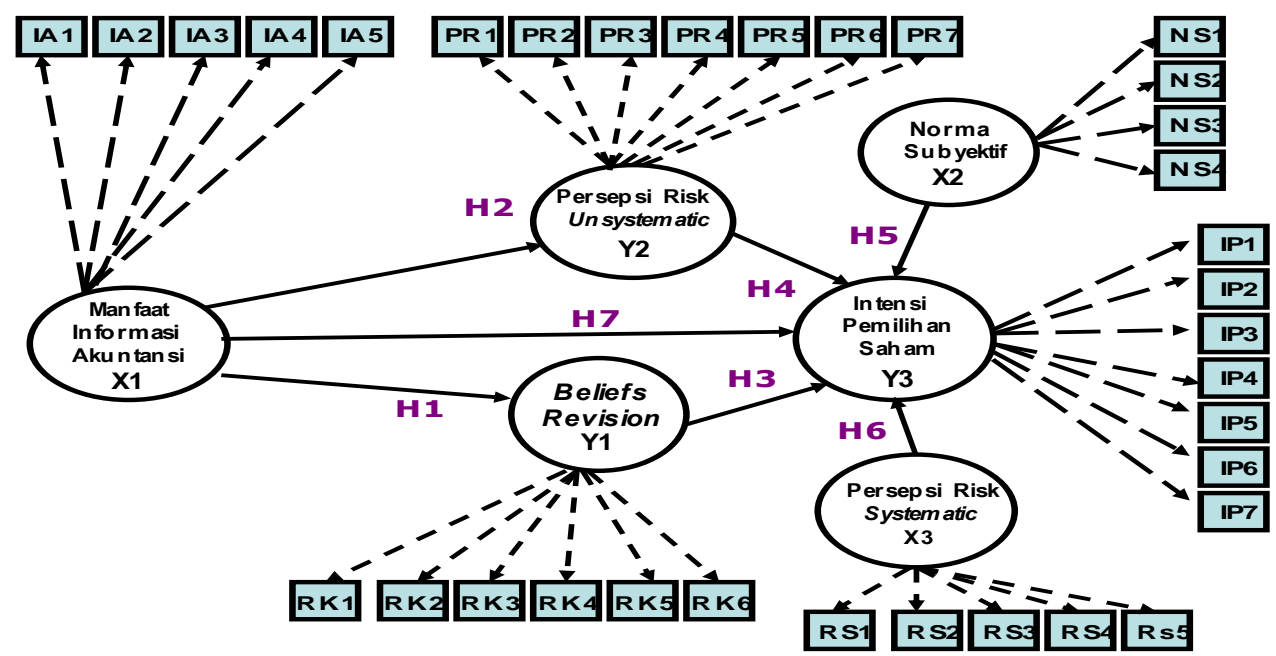

\section{Result and Disscusion}

\subsection{Data Collection}

The research data is collected through surveys. A number of distributed questionnaires to respondents is 250 sheets, and 192 sheets have been returned. The response rate of $73 \%$. Data regarding the deployment process, reception, and processing contained in Table 1.

Table 1 
An overview of Dissemination and Acceptance Questionnaire

\begin{tabular}{ll}
\hline Note & Number \\
\hline Distributed Questionaire & 250 copies \\
Returned due to unknown address & 9 copies \\
Dissemination Questionnaire number & 241 copies \\
& \\
Returned questionnaire & 192 copies \\
Returned presentage & $79,66 \%$ \\
& 178 copies \\
Usable quistionaire & $73 \%$ \\
Usable presentage &
\end{tabular}

Source: Data processed

\subsection{Characteristics of Respondents}

Securities analysts demographics show the largest characteristics at the age of 3135; male gender; undergraduate education; education of forecasting and valuation capital market; work duration 6-10 years old; The main task is research, analysis, and recommendations; as well as the type of fundamental analysts.

\subsection{Test Reliability and Validity}

Reliability tests are conducted by calculating Cronbach alpha and defined to be reliable if it has a value of more than 0.60 (Nunnally, 1978). Cronbach alpha value is instrumented ranging from 0.742 up to 0.948 . While the construct validity testing is conducted by factor analysis by the MSA values above 0.50 (Kaiser and Rice, 1974). MSA value of the study is ranged from 0.634 up to 0.837 . Test results of reliability and validity contained in Table 2 .

Table 2.

Reliability Testing Result and Variable Validity

\begin{tabular}{lll}
\hline Variable & Reliability & Validity \\
\hline Variable Reliability Validity & 0,870 & 0,801 \\
Benefits of Accounting Information & 0,791 & 0,751 \\
Unsystematic Risk Perception & 0,742 & 0,634 \\
Subjective Norm & 0,808 & 0,777 \\
Systematic Risk Perception & 0,801 & 0,791 \\
Selection intention Shares & 0,948 & 0,837 \\
\hline
\end{tabular}

Source: Data processed 


\subsection{Test assumptions Structural Equation Modelling (SEM)}

Test of SEM assumptions includes sample size discussions of 178 corresponding to the Maximum Likelihood Estimation. The value of Critical Value Ratio multivariate assessment of normality of 0.814 which is at a critical value $-1.96-+1.96$ so that indicating a normal distribution of data. The value of the sample covariance matrix determinant, i.e. 5.5504 which is far from the numbers 0 proves there are no multicollinearity and singularity symptoms. While the value of Mahalanobis distance is higher than the Chi-Square table or value $\mathrm{p} 1<0.001$ hence there is no outlier.

\subsection{Compliance Test Model (Goodness-of-fit test)}

The test results of the Goodness-of-fit test in Table 3 which demonstrate the value of the probability level from the model is 0,211 above the minimum required value of 0.05. The value of Chi-Square, RMSEA, GFI, AGFI, CMIN / DF, TLI and CFI obtained is $299773,0019,0984,0966,1066,0976$, and 0960. Generally, this research model is accepted concluded.

Table 3.

Compliance Index Structural Equation Modeling (SEM)

\begin{tabular}{llll}
\hline Criteria & Cut of Value & Calculation Results & Description \\
\hline Chi-Square $\left(\chi^{2}\right)$ & Small expected & 299,773 & $\chi^{2}$ with df $=281$ is 322 \\
& & & Accepted \\
Sign. of Probability & $\geq 0,05$ & 0,211 & Accepted \\
RMSEA & $\leq 0,08$ & 0,019 & Accepted \\
GFI & $\geq 0,90$ & 0,984 & Accepted \\
AGFI & $\geq 0,90$ & 0,966 & Accepted \\
CMIN/DF & $\leq 2,00$ & 1,066 & Accepted \\
TLI & $\geq 0,95$ & 0,976 & Accepted \\
CFI & $\geq 0,95$ & 0,960 & Accepted \\
\hline
\end{tabular}

Source: Data processed

\subsection{Hypothesis testing}

The analysis result using the AMOS program is contained in Table 4. This result shows influences among variables from the $\mathrm{H} 1$ until $\mathrm{H} 7$ give significance probability (p) under 0:05, so the hypothesis being tested significantly acceptable. 
Table 4.

Structural Model Parameter Estimation

\begin{tabular}{llllll}
\hline Variable & Estimate & S.E. & C.R. & Prob. & Hypothesis \\
\hline $\begin{array}{l}\text { Benefits of Accounting Information } \\
(\mathrm{X} 1) \rightarrow \text { Revision Confidence Y1) }\end{array}$ & 1,8231 & 0,1665 & 5,5400 & 0,0110 & H1* \\
$\begin{array}{l}\text { Benefits of Accounting Information } \\
(\mathrm{X} 1) \rightarrow \text { unsystematic Risk Perception }\end{array}$ & 1,4395 & 0,2634 & 5,4636 & 0,0000 & H2* \\
$(\mathrm{Y} 2)$ & & & & \\
$\begin{array}{l}\text { Revised Confidence (Y1) } \rightarrow \text { Intensi } \\
\text { Election Stocks (Y3) }\end{array}$ & 1,1265 & 0,4594 & 2,4517 & 0,0142 & H3* \\
unsystematic Risk Perception (Y3) $\rightarrow$ & 0,9090 & 0,2460 & 3,6944 & 0,0002 & H4* \\
$\begin{array}{l}\text { Election Shares intention (Y3) } \\
\text { Subjective norm (X2) } \rightarrow \text { intention of }\end{array}$ & 0,6021 & 0,2538 & 2,3720 & 0,0176 & H5* \\
$\begin{array}{l}\text { Election Shares (Y3) } \\
\text { Systematic Risk Perception (X3) } \rightarrow\end{array}$ & $-0,5120$ & 0,2285 & $-2,237$ & 0,0217 & H6* \\
intention of Election Shares & & & & & \\
\hline
\end{tabular}

Significant at $\alpha$ pada $\alpha=5 \%$

\subsection{Discussion}

H1. The benefits of accounting information influence the revision beliefs.

Benefits of the accounting information influence positively towards beliefs revision with a path coefficient of 1.8231 , the $\mathrm{CR}$ value of 5.5400 , and the significance probability value (p) of 0.0110 which is less than 0.05 . Study findings showed that securities analysts are positive on the financial statements of the company and use it for analysis. Securities analysts become more informed by the analysis to revise beliefs regarding the performance, prospects and earning power in the future. The implication, securities analysts, conduct stock repositioning decisions. It shows that the accounting information has the understandable, relevant and reliable quality and information content for decision making. Securities analysts behave sophisticated and right in assessing and interpreting the information which has economic value. Thus, financial statements give information usefulness to securities analysts. Hence, the information contains information for securities analysts and accounting information in decision usefulness. This finding is consistent with the results of research Beaver (1989), Barberis and Thaler (2003), as well as Stuerke (2005). 
H2. The Benefits of accounting information influence the perception of risk unsystematic.

Benefits of accounting information have a positive influence on the unsystematic risk perception with a path coefficient of 1.4395 , the value of CR for 5463, and the significance probability value (p) 0,000 less than 0.05 . This study's findings indicate securities analysts to be positive about the company's risk perception. This is due to the accounting information could be able to provide predictions and realization of analysts' expectations, as well as show the performance and prospects of companies that provide interpretation and belief in the company's stock which is risky because of the alarming, negative consequences, uncontrolled, and dangerous company's financial condition. With the risky interpretation, there is an understanding in the securities analyst cognitive for the experienced each emitent stock in the stock market indicating risk following the risk preference view of risk seekers, risk averter, and risk neutral. The study shows that the company financial condition is given the perception of risk. The empirical findings support the Koonce results in et al., (2004), Capstaff (1992), Lee (1999), and Beaver et al. (1970).

\section{H3. Beliefs revision effects the intention stock selection.}

Beliefs revision influences positive on intentions of stock selection with a path coefficient of 1.1265 , the $\mathrm{CR}$ value of 2.4517 , and the significance probability value (p) of 0.0142 which is less than 0.05 . The study finds the motivation for the primary belief revision relating stock selection which was positive so that it supports the intention to pick the stocks. A positive response to the belief revision is caused by the belief of net income and companies dividend containing news and information, as well as the satisfaction of the financial statements performance which is signal good news.

Confidence determines the behavior of decision-making for securities analysts to conduct interpreting and analyzing the information signal for further information to determine whether the signal is valid and reliable. The signal information is interpreted to change the core beliefs because it provides economic value and 
information content which is reflected in increasing and decreasing stock prices on trade transactions. The implication, the reduced stock value is revised with the increased stock value. This process shows that securities analysts have an investment interest, financial investment knowledge, as well as planning and controlling investment. The results prove that the intentions are powerful in the stock selection for securities analyst because of the sophisticated behavior in processing and analyzing information. This finding is consistent with the research by Wahlund and Gunnarsson (1996), Bruns (1968), and Hunton and McEwen (1997).

H4. Unsystematic risk perceptions affect the intentions of stock selection.

Unsystematic risk perception influences positive to the intentions of stock selection with a path coefficient of 0.9090 , the CR value of 3.6944, and the significance probability value (p) of 0.0002 less than 0.05 . Securities analysts observe that the stock is the risky financial instruments. Thus it is susceptible to all sorts of events and information. Also, it can be looked as a signal bad news that decreases the value of the issuer's shares because of the demonstrating of performance and prospects of the risky company without economic value. The implication, it influences the decision making of the stock selection

The fundamental securities analysts conduct the intentions process by basing on the time horizon preferences and the long-term prospects, the self-control and the attitude towards a neutral risk-taking. Securities analysts tend to be prudent and rational to decide risky decision in the stock selection. Securities analysts evaluate the stock candidate performance and determine the selected candidates based on the investment interests and risky preferences attitudes. The intention of stock selection depends on financial statement information. Securities analysts are indifferent to the risk. They have a neutral risk preference. This finding is consistent with the results of Siegel and Marconi (1989), as well as Chen and Steiner (1999).

H5. Subjective Norms influence the intentions of stock selection. 
The test results showed a subjective norm positively influences the intentions of stock selection with a path coefficient 0.6021 , the CR value of 2.3720 , and the value of significance (p) 0017 less than 0.05. Securities analysts positively influence the strength of the observer influence, the friends' influence, and the regulator's influence on the intention of stock selection. The study found that the most powerful influences to determine the intention of stock selection are only at the friends' influence. The social environment around these securities' analyst has a strong commitment to influence securities analysts to determine the intention to stock selection. The view influences of friends give a major contribution to determine the candidate and performance shares. Because of the different cognitive processes in the securities analysts, they tend to provide instructions and descriptive analysis differently to demonstrate the performance of each stock. Securities analysts prefer the friends' opinions and suggestions because they more trusting in consideration and evaluation than the suggestion of the observer and regulator. This finding is consistent with the research results of Bhattacherjee (2000), Hailu et al. (2005), Hite (1988), Shin, et al., (1995), Tim JSX (1997).

H6. Systematic risk perceptions influence the intentions of stock selection.

The test results show systematic risk perception negatively affect the intention of stock selection with path coefficient -0.5120 , CR value of -2.2370 , and the value of significance (p) 0.0217 less than 0.05 . It indicates that securities analyst perceives a high systematic risk or an unpredictable accurately so that the intentions of the stock selection becomes low. The securities analysts influence negatively on systematic risk perception in the Indonesia Stock Exchange. Thus, as an individual of securities analysts, he can not accurately predict his external systematic risk. The high risks derive from economic turbulence, the country's political conditions, the changes and developments in information technology, the public policy, the financial market conditions, and the changes in interest rates responded negatively by securities analysts. Thus, analysts perceive the external environment is unpredictable. Securities analysts understand that the situation above is caused by external aspects beyond his 
control that will affect the mechanism in the Stock Exchange. These conditions give negative expectations with a range of views on all market participants.

The security of the risk assets and their uncertainty environmental which cannot be avoided, may not provide definitive information or it is misinterpreted through the assessment information. In that circumstances, many market players conduct not rational deviate actions, such as panic and mass euphoria which leads to getting loss control. Securities analysts avoid the process of worrying about making the wrong decision, as well as postponing the decision for a period of time or having no decision. Thus, the intention process in the securities of stock selection becomes neutral. As a result, the process will be prudent, self-control, risk neutral, the repositioning of investment planning and control, low investment interest, as well as evaluating all share candidates through investment knowledge (Nofsinger, 2005).

H6. The Benefits of accounting information influence the intentions of stock selection

The test results show that the benefits of accounting information have a positive impact on the intention of stock selection with path coefficient 0.8090 , the $\mathrm{CR}$ value of 2.4694, and the value of significance (p) 0,002 less than 0.05. Accounting information is the financial statements performance as good signal news. The belief determines the behavior of decision-making for securities analysts to interpret information signal and analyze the further information to determine whether the signal is valid and reliable. The analyzed signal information provides the valuable information content. The information is in the value of the firm in the company's stock price, resulting in the increase or decrease of the stock prices in trade transactions. It causes analysts to make decisions of stock selection.

Beliefs determine the decision-making behavior for the interpretation of the information. It comes from cognitive through the understanding center of information processes, such as memory, attention, perception, thought, knowledge, and judgment. Then, there is an intentional process to estimate the return of a security interest. 
Manifestations are the reality of expected values and risk perception as well as the intentions of securities analysts to take decision-making of the stock selection. Each of the securities analysts gives different results because of the different knowledge and beliefs. The antecedent forms the intention to select stocks the antecedent as the causes of behavior, i.e. information. Information can be received in the form of financial information and non-financial information. One of the financial information forms is the accounting information in the form of a financial statement. The financial statement provides information of financial performance, prospects, and the value of the company. Also, it forms a fundamental knowledge of finance as a conviction for the perpetrators in the good stock selection. That knowledge has a positive or negative result and influences the attitude to take the stock selection (positive) or leave from the stock selection (negative). The results of this study are consistent with the results of research Wahlund and Gunnarsson (1996), Bruns (1968), and Hunton and McEwen (1997). The results are not consistent with findings from studies Blanthorne (2000).

Table 5 .

Indirect Relationship

\begin{tabular}{llll}
\hline Hubungan Variable & $\begin{array}{l}\text { Total } \\
\text { Variable }\end{array}$ & $\begin{array}{l}\text { Direct } \\
\text { Relations }\end{array}$ & $\begin{array}{l}\text { Indirect } \\
\text { Relationship }\end{array}$ \\
\hline $\begin{array}{l}\text { The benefits of accounting information } \\
\text { Selection Intention shares }\end{array}$ & 3,6031 & 1,7530 & 1,9501 \\
\hline $\begin{array}{l}\text { The benefits of accounting information } \\
\text { Selection Intention shares }\end{array}$ & 2,3306 & 0,8746 & 1,4560 \\
\hline Source: Processed Data & & & \\
\hline
\end{tabular}

Based on Table 5 about indirect influence revision of beliefs in the benefits relationship of accounting information with the stock selection indirect influence intention of 1.9501 which is higher than the direct influence of 1.7530. The indirect influence of unsystematic risk perception on the benefits relationship of accounting information with the intention of stock selection shows the indirect influence of 1.4560 which is higher than the direct influence of 0.8746. This means that the revision of beliefs and risk unsystematic perceptions increases the benefits of accounting information to the stock selection intentions. The analysis results proved 
that unsystematic risk perception and belief revision could provide the improvement of stocks selection intention. Hopefully, it obtains the return as the profit prospects in the future by doing diversification through adverse selection return so that it will be helpful, prospective, and valuable for the accounting information content. This is consistent with the results studies of Goodwin et al. (1986), Barth et al. (2001), Ball and Brown (1968), Snelbecker et al. (1990), Gordon (1962), Beaver (1989), Beaver et al. (1979), East (1993), as well as arrozi $(2010,2011,2012)$.

\section{Conclusion, Implication, and Limitation}

\subsection{Conclusion}

This study proved the support of hypothesis $1,2,3,4,5,6$, and 7 . The intention in stock selection may change due to the more powerful individual factors than the environmental factors. The benefits of accounting information are the individual factors having stronger influence which is followed by a beliefs revision, the perception of risk, and subjective norms. Framework theory developed in this study is to test the intentions of securities analysts in stock selection due to the proven of consideration accounting information. The stock selection depends on the stock price changes which reflect the entire information. Thus, securities analysts change beliefs and decisions, as well as repositioning actions of selected stock because of accounting information content. The intention of stock selection is arranged by an indication of how much-planned effort is. It depends on the benefits of the accounting information, the revision of beliefs, the risk perceptions and the subjective norms.

Decision making of securities analyst is to hold shares than to do sell or to buy stock. This is conducted for self-control and security of the situation he knows well. Securities analyst motif does not produce quick profits but constant. This is consistent with the analysts main objective to generate income in the long-term time horizon to increase the achievement of capital investment. Long-term securities analysts want a comprehensive information collection regarding an investment decision and a long waiting period before being reactive in the market. The securities analysts manage the decision and require control through its long-term outlook, as well as taking a risk 
when the investment is not profitable in the short term but providing security in the long term.

The meaning of these findings is the sophisticated securities analysts in the accounting information analysis to take the rational economic decisions. The fundamental analysis prevents the speculation process, the issue, and the misleading rumors. This proves that the accounting information is relevant, reliable, and fairness that is beneficial to understand the needs and problems decision faced by the user. Also, the intention of stock selection is formed by the users' knowledge and experience and the influence of other people's experiences. This process shows the halo effect due to the influence of friends/colleagues made a major contribution to determine the candidate shares election that can change the direction of stock investment. Thus, securities analysts tend to be prudent, sophisticated, volitional, and neutral risk preferences.

\section{2 limitation}

Some of the perceived limitations interfere in this study are:

1. The contribution of the global financial crisis in the United States and Europe that disrupt the operational mechanism of world capital markets including the Indonesia Stock Exchange. These conditions result in the users to have a pessimistic and very risky expectation. This study hopefully will be better by taking the proper time allocation on the bullish or bearish capital market conditions. 2. A little understanding of sophisticated securities analysts behavior in the decision process. This provides an explanation why one securities analyst with other securities analysts has higher or lower levels than the others. The same knowledge and information influence the possibility of securities analysts. Hence, the role hallo effect should be taken into consideration.

\subsection{Implication}

Based on the conclusions and limitations above, the proposed recommendation is for subsequent research are: 
1. To develop a model in the theory of reasoned action with variables induction such as variable of an environment, risk, pattern, style decisions, factors controlled, as well as internal factors either as an intervening variable or moderating the intention models in stock. This variable will give the proper behavior because it can explain the motives and interests of securities analysts to behave in stock selection and actions in providing stock recommendations to investors. 2. Do some research on the condition of the bearish or bullish capital markets and the conducive economy. It will be able to provide a comprehensive and structural explanation regarding securities analysts attitudes. 3. The need for different samples in this research, especially for variable attitudes and actions implications. It is advisable to take broker and investor samples for further study.

\section{References}

Agung Ardyatmo, Harris Hadinata, and Raymond Sondang, 2007, Menguak Petuah Para Analis, Kontan, No 18, Tahun XI, 5 February 2007, http://www.kontan-online.com"

Ajzen, Icek, 1988. The Theory of Planned Behavior, Organizational Behavior, and Human Decision Processes, 50 (2).

Arrozi, MF, 2010, Revisi Keyakinan Atas Sinyal Informasi Akuntansi, Jurnal Akuntansi dan Auditing Indonesia, Vol. 10, No. 2, Desember, pp 25-51.

Arrozi, MF., 2011, Preferensi Investor Dalam Pengambilan Keputusan Investasi Sekuritas Di Bursa Efek Indonesia, Simposim Riset Ekonomi V, ISEI, Oktober, Surabaya.

Arrozi, MF, 2012, Model Perilaku Mental Investment dan Mapping Risk Preference pada Investor Individu di Bursa Efek Indonesia, Hasil Penelitian Fundamental Dengan Dana DIKTI Tahun Anggaran 2012, Universitas Esa Unggul Jakarta.

Arrozi, MF, Maslichah, Nur Diana, 2013, Karakteristik Kualitatif Informasi Dalam Revisian Keyakinan Pengguna Untuk Penilaian Prospek Sekuritas Di Bursa Efek Indonesia, Hasil Penelitian Fundamental Dengan Dana DIKTI Tahun Anggaran 2013, Universitas Esa Unggul Jakarta.

Ball, R. and P. Brown, 1968. An Empirical Evaluation of Accounting Income Numbers, Journal of Accounting Research, pp 159-178.

Barberis, Nicholas, and Thaler, Richard, 2003, Handbook of the Economics of Finance, Elsevier Science. 
Barth, M.E., W.H. Beaver, and W.R. Landsman, 2001, The relevance of the Value Relevance for Accounting Policy Makers: Another View, Journal of Accounting and Economics, pp. 1-38.

Beaver, W.H., Kettler, P., and Scholes, M., 1970. The Association between market determined and accounting determined risk measures, The Accounting Review, Vol. 6, pp. 654 682.

Beaver, W.H., R. Clarke, and W.F., Wright, 1979. The Association Between Unsystematic Security Return and The Magnitude of Earnings Forecast Errors, Journal of Accounting Research, pp. 316-340.

Beaver, W.H., 1989. Financial Reporting: An Accounting Revolution, Second Edition, Englewood Cliffs, New Jersey: Prentice Hall.

BEJ, 1997. Tingkat Pengenalan Terhadap Pasar Modal Pada 7 (tujuh) Ibukota Propinsi, Jakarta : BEJ. Resource Productivity Center Marketing \& Social Research.

Bhattacharjee, Anol, 2000, Acceptance of e-commerce services: the case of electronic brokerages.http://www.informatik.uni-trier.de/ ley/db/journals/tsmc/tsmca30.html" IEEE Transactions on Systems, Man, and Cybernetics, Part A 30 (4): pp. 411-420.

Blanthorne, Cynthia M., 2000. The Role of Opportunity and Beliefs On Tax Evasion: A Structural Equation Analysis. Dissertation, Arizona State University.

Bruns, William J. Jr., 1968. Accounting Information and Decision Making: Some Behavioral Hypotheses, The Accounting Review, July, pp. 469-480.

Capstaff, John, 1992. The Usefulness of UK accounting and market data for predicting the perceived risk class of securities, Accounting and Business Research, Vol.22, No.87, pp 219-228

Chen, S., and Hsu, K. 2005. Perceived usefulness of annual reports and other information, Paper presented in the Research Forum Session at the annual meeting of the American Accounting Association, San Francisco.

Chen, Carl R, and Steiner, Thomas L. 1990. Managerial Ownership and Agency Conflict: A Nonlinear Simultaneous Equation Analysis of Managerial Ownership, Risk Taking, Debt Policy, and Dividend Policy. The Financial Review. Vol 34, pp. 119-136.

Chow, Wing S. and Lai Sheung Chan, 2008, Social network, social trust and shared goals in organizational knowledge sharing, Information \& Management, Volume 45, Issue 7, November 2008, Pages 458-465, Elsevier.

Easton, P.D., and M.E. Zmijewski, 1989. Cross-Sectional Variation In The Stock-Market Response to Accounting Earnings Announcement, Journal of Accounting and Economics, July, pp 117-141. 
East, Robert, 1993. Investment Decision and The Theory of Planned Behaviour, Journal of Economic Psychology, Vol 14, pp. 337-375.

Epstein, M.J. 1975. The usefulness of annual reports to corporate shareholders. Los Angeles Bureau of Business and Economic Research, California State University.

FASB tentang SFAC No.1, Tujuan Pelaporan Keuangan Oleh Perusahaan Bisnis, 1980.

Farid Harianto dan Siswanto Sudomo, 1998. Perangkat dan Teknik Analisis Investasi, Jakarta, Penerbit: PT. Bursa Efek Jakarta (BEJ).

Ferris, K. R., Hiramatsu, K., and Kimoto, K., 1990. Accounting Information and Investment Risk Perception in Japan, Journal of International Financial Management and Accounting, 1 (3), pp. $232-243$.

Fishbein, Martin, and Ajzen, Icek, 1975. Belief, attitude, intention, and behavior: an introduction to theory and research, Massachusetts: Addison-Wesley.

Gibson, L. James, Ivancevich, M. John, dan Donnelly. James L. Jr., 1997. Organisasi: Perilaku, Struktur, dan Proses, Edisi 8, Jakarta: Penerbit Binarupa Aksara.

Goodwin, J., K.R. Sawyer, and K. Ahmed, 1986. The Relevance of Value, The Social Science Research Network Electronic Paper Collection, http://papers.ssrn.com /abstract=244261, pp. 1-31.

Goldberg, Joachim, and Rudiger von Nitzsch, 2001. Behavioral Finance, John Wiley \& Sons Ltd, England.

Gordon, L.A., and V.K. Narayanan, 1984. Management Accounting system: Perceived Environmental Uncertainty and Organization Structure: An Empirical Investigation, Accounting, Organizations and Society, Vol. 9, pp. 33-47.

Hair, J., F., Jr., R.E. Anderson, R.L. Tatham, and W.C. Black, 2007. Multivariate Data Analysis with Readings, Indiana: Macmillan Publishing Company.

Hailu, Getu, Ellen W. Goddard, and Scott R. Jeffrey, 2004, Do Decision Makers' Debt-risk Attitudes Affect the Agency Costs of Debt? Annual meeting of the Canadian Agricultural Economics Society, Halifax, June,

Hartono, Jogiyanto, 2008. Teori Portofolio dan Analisis Investasi, Edisi 5, Yogyakarta: BPFE.

Hartwick, J., and Barki, H., 1994, Explaining the Role of User Participation in Information System Use, Management Science (40:4), pp. 440-465.

Hite, P., 1988. The Effect of Peer Reporting Behavior on Taxpayer Compliance. The Journal of American Taxation Association (Spring). 
Ho, Simon S. M, and Wong, K. S., 2004. 'Investment Analysts' Usage and Perceived Usefulness of Annual Corporate Reports', Corporate Ownership and Control, 1, pp. 61-71.

Hoggart, R., and H., Einhorn, 1992. Order Effect in Belief Updating: The Belief-adjustment model, Cognitive Psychology, 24(1), pp 1-55.

Ikatan Akuntan Indonesia, 2012, Standar Akuntansi Keuangan, per 1 Juni 2012, Jakarta: Penerbit Salemba Empat.

Investor, 2007. Ekonomi 2007: Secercah Cahaya Ditengah Kabut, Edisi 161, Jakarta.

Jones, C.P, 2006. Investments Analysis and Management, New York: John Wiley \& Sons, Inc, 8th Edition.

Kamus Besar Bahasa Indonesia, 1995, Tim Penyusun Kamus Pusat Bahasa, Jakarta: Balai_Pustaka"

Kaiser, H.F, and J. Rice, 1974. Educational and Psychological Measurement, 34, (I), P. 111117.

Kim, Linsu, and Lim, Y., 1988, Environment, Generic Strategies, and Performance in a Rapidly Developing Country, Academy of Management Journal, Vol. 31, pp. 802827.

Koonce, Lisa, and Mercer, Molly, 2004, Using Psychology Theories in Archival Financial Accounting Research, Journal of Accounting Literature, pp 175-190.

Lee, C.M.C., 1999, Accounting-Based Valuation: Impact on Business Practices and Research, Accounting Horizons 13: 413-425.

Luo, Yadong, 1999. Environment-Strategy-Performance Relation in Small Business in China: A Case of Township and Village Enterprises in Southern China, Journal of Small Business Management, January, pp. 37-52.

Matlin, Margaret W., 1998, Cognition, Fourth Edition, Ganeseo, New York: Harcourt Brace College Publisher.

Nofsinger, John R., 2005, The Psychology of Investing, Pearson Education, Second Ed., NJ: Upper Saddle River.

Nunnally, J. C., 1978, Psychometric Theory, Hightstown, NJ: McGraw Hill, I.

Prabowo, Tommy, 2000, Mengharapkan Laporan Keuangan Plus, Media Akuntansi, No. 10, Year. VII, Juni, Jakarta

Ricciardi, Victor, 2004, A Literature Review of Risk Perception Studies in Behavioral Finance: The Emerging Issues, Presented at the 25th Annual meeting of The Society for The 
Advancement of Behavioral Economics (SABE) Conference, New York University, May 15-18, 2007.

Robbins, Stephen P., 1996. Perilaku Organisasi: Konsep, Kontroversi, Aplikasi, Edisi Bahasa Indonesia, Jakarta: Penerbit PT. Prenhalindo.

Scott, William R., 2011. Financial Accounting Theory, $6^{\text {th }}$ ed, Toronto: Pearson Education Canada Inc.

Selva, Mohan, 1995. Earnings and Stock Selection, http://www.ssrn.com": GEL Classification: M41.

Shin, Chuah Hooi, T. Ramayah, and Sheeva Jahani, 1995, Using Theory of Reasoned Action (TRA) to Explain Intention to Share Knowledge among Academics, http:// www. apera08.nie.edu.sg/proceedings, Technology Management Lab, School of Management, USM, Minden.

Snelbecker, E. Glenn., Roszkowski J. Michael, and Cutler, E. Neal, 1990, Investors' Risk Tolerance and Return Aspiration, and Financial Advisors' Interpretations: A Conceptual Model and Exploratory Data, The Journal of Behavioral Economics, Vo. 19, No. 4, pp. $377-393$.

Statement of Financial Accounting Concepts (SFAC) No. 2, Qualitative Characteristic of accounting Information, 1980, Publication Department FASB, Stamford, Connecticut.

Stuerke, Pamela S., 2005, Financial analysts as users of accounting information: Evidence about forecast revision activity after earnings announcements, International Journal of Managerial Finance, Vol. 1 (1), pp. 8-24.

Suad, Husnan, 2006, Dasar-Dasar Teori Portfolio, Edisi Kelima, Yogyakarta: Penerbit UPP AMP YKPN, Oktober.

Suwarjono, 2008, Teori Akuntansi: Perekayasaan Pelaporan Keuangan, Edisi Ketiga, Juli, Yogyakarta: BPFE

Wahlund, Richard, and Jonas Gunnarsson, 1996, Mental Discounting and Financial Strategies, Journal of Economic Psychology 17, pp 709-730. 
MF. Arrozi Adhikara, et al.

intentionally blank 